\title{
Coğrafya Öğretmenlerinin İş Doyum Düzeylerinin İncelenmesi
}

\begin{abstract}
Nadire KARADEMİ**
Öz

$\mathrm{Bu}$ araştırma coğrafya öğretmenlerinin farklı değişkenler açısından iş doyumu düzeylerini ortaya koymak amacıyla yapılmıştır. Araştırmada, betimsel nitelikli tarama modeli kullanılmıştır. Araştırmanın çalışma grubunu, 2014-2015 eğitim- öğretim yılında Milli Eğitim Müdürlüğüne bağlı okullarda görev yapan toplam 324 coğrafya öğretmeni oluşturmaktadır. Veri toplama aracı olarak "Minnesota Doyum Anketi" kullanılmıştır. Bu envanter, araştırmacı tarafından hazırlanan "kişisel bilgi formu" ile birlikte örneklemi oluşturan coğrafya öğretmenlerine elektronik ortamda gönderilmiş ve verilerde aynı yoldan geri alınmıştır. Elde edilen veriler normallik testine tabi tutulduktan sonra parametrik test gruplarından olan ikili karşılaştırmalar için bağımsız örneklem t-testi, çoklu karşılaştırmalar için tek yönlü varyans analizi (ANOVA) testleri ile çıkarımsal analizler yapılmıştır. Elde edilen sonuçlar çalışmaya katılan coğrafya öğretmenlerinin iş doyumu puanlarının arazi gezi ve inceleme olanaklarına, fiziki çevre (ders araç ve gereç) yeterliliğine çalışılan kurum ve çalışılan okul değişkenlerine göre anlamlı farklılıklar gösterdiği; cinsiyet, yaş ve coğrafya dersi öğretim programı değişkenlerine göre ise farklılık göstermediği şeklindedir.
\end{abstract}

Anahtar Kelimeler: Coğrafya öğretmeni, Eğitim, Coğrafya, İş doyumu.

\section{An Analysis for The Job Satisfaction Levels of The Geography Teachers}

\begin{abstract}
The purpose of this study is to analyse the job satisfaction levels of the geography teachers in terms of different variables. Descriptive survey model was used in the study. The study group was comprised of 324 geography teachers in total who are working in the schools under National Education Directorate during 2014-2015 school year. "The Minnesota Satisfaction Questionnaire" was the data collection tool. This inventory and "personal information form" which was prepared by the researcher were sent electronically to the geography teachers in the research. The data was also collected electronically. The collected data were first subjected to normality test. Afterwards, in order to do inferential analysis, independent sample t-test was used for the paired comparison of parametric test groups and one-way analysis of variance (ANOVA) was used for the multiple comparisons. According to the results obtained, the job satisfaction ranking of the geography teachers in
\end{abstract}

\footnotetext{
*Yrd.Doç.Dr, Kahramanmaraş Sütçü İmam Üniversitesi, Fen-Edebiyat Fakültesi, Coğrafya Bölümü, n.karademir45@gmail.com
} 
the study vary across the opportunities of the field exploration and excursion, the sufficiency of the physical environment (equipments for the lecture) and the variables of the institution and the school. However, the ranking does not vary according to the teachers' gender, age or variables in the curriculum for geography.

Keywords: Geography teacher, Education, Geography, Job satisfaction.

\section{GíRiş}

İş doyumu, geçmişten günümüze güncelliğini kaybetmeyen, kişilerin işe daha olumlu yaklaşmalarını işlerinde mutlu başarılı ve üretken olmalarını sağlayan önemli bir kavramdır. Çalışanın yaptığı işten hoşlansa da hoşlanmasa da işiyle ilgili bileşenlerin tümüne karşı olan genel tutumunu ifade eder (Shraibman, 2008; Shields, 2007). İş doyumu, kişinin işten memnun olma düzeyi ve işi ile ilgili olumlu ya da olumsuz duygularıdır. Hayatın her döneminde insanlar yaşamlarını sürdürebilmek için bir işe ihtiyaç duymuştur. Eski dönemlerde avcılık, toplayıcılık, tarım ve savaş aletlerinin yapımı ile uğraşmış, ilerleyen dönemlerde ihtiyaçlarının değişmesi ve sanayi devrimi ile de daha farklı işler yapmaya başlamışlardır. Böylece iş doyumu gibi, işle ilgili yeni kavramlar ortaya çıkmıştır (Demirtaş ve Ersözlü, 2010).

Genel olarak çalışanların işlerine ilişkin duygularının bir reaksiyonu olarak tanımlanan iş doyumu kavramı, ilk kez 1920'lerde ortaya atılmıştır.Bu kavramın önemi ise 1930-1940'l1 yıllarda daha iyi anlaşılmıştır (Agho ve diğ., 1993: 1007).Literatür tarandığında iş doyumu ile ilgili birçok tanıma rastlanmakla birlikte bu tanımların genelde birbirleriyle benzeştiği görülmektedir.İ̧s doyumu çalışanın işle ilgili beklentileri ve bu beklentilerin karşılanma düzeyinin kendisinde yarattığı olumlu ya da olumsuz tutumlar, hazlar ve duyguların bütünüdür. İşin iyi ya da kötü, olumlu ya da olumsuz olması kişinin doyum ya da doyumsuzluk hislerinin oluşmasına katkıda bulunur (Olorunsola, 2010). Çalışanın iş ortamından kaynaklanan unsurlara karşı gösterdiği tepkiler ve bireysel ihtiyaçların karşılanma düzeyleri ile bireysel istek ve beklentiler arasındaki fark ( Çetinkanat, 2000) olarak da tanımlanan iş doyumu, çalışanların işlerini ne ölçüde sevdikleri, iş doyumsuzluğu ise, çalışanların işlerini ne ölçüde sevmediklerinin ifadesidir. Genel anlamda ise iş doyumu ise çalışanların işlerinden duydukları kişisel memnuniyettir (Olorunsola, 2010). Maslow'un “İhtiyaçlar Hiyerarşisi Kuramı"'nda insan ihtiyaçlarının hiyerarşik bir yapı içerisinde ortaya çıktığı, her bir ihtiyacın önemli olduğu ve belli bir ölçüde karşılanması gerektiği ifade edilmekte, sonuçta ise iş doyumunun yaşandı̆̆ı açıklanmaktadır (Karataş ve Güleş, 2010). İş hayatında da doyurulan "değerlerin önem derecesi" ne kadar yüksekse iş doyumu da o kadar yüksek olacaktır (Wagner ve Hollenbeck, 2010:138).

Çalışanların iş doyumlarını etkileyen birçok faktör bulunmaktadır. Fakat bu faktörler için yapılan en yaygin siniflandırma bireysel ve örgütsel faktörler olarak iki grup altında ele alınan sınıflama şeklidir. İş doyumunu etkileyen bireysel faktörler arasında; bireyin demografik özelliklerinden yaş, cinsiyet, eğitim durumu, hizmet süresi, , mesleki konum, kıdem, zekâ, sosyo kültürel çevre, medeni durum ve iş deneyiminin olup olmaması ile başarı güdüsü, takdir edilme duygusu, saygı görme ve çalışanın psiko-sosyal özellikleri olduğu görülmektedir. İşin niteliği, yönetim tarzı ve denetim biçimi, iletişim, ücret, gelişme ve yükselme imkânları, işin doğası ve niteliği, iş yerinin fiziksel koşulları ve sosyal ortamı, güvenlik duygusu, çalışma şartları, rekabet, denetim, birlikte çalışan kişiler ise çevresel ya da örgütsel faktörlerdir (Balc1, 1985; Sabuncuoğlu ve Tüz, 2005). 
İş doyumu, bilişsel, duygusal ve davranışsal özelliklerin karışımı olarak "içsel”, "dışsal” ve "genel" iş doyumu şeklinde açıklanmakta, çalışanın ücret; ekonomik ödüller gibi çalışmanın sonucunda elde ettiği doyum "dişsal doyum"; başarma duygusu gibi çalışma sırasında hissedilen doyum ise "içsel doyum" olarak ifade edilmektedir (Balc1, 1985). İş doyumu hem örgütsel amaçlar açısından hem de bireylerin daha mutlu bir yaşam sürdürmeleri açısından büyük önem taşımaktadır.

\section{1 Öğretmenlerde İş Doyum}

İş doyumu tüm meslekler için önemli olduğu kadar, sürekli özveri gerektiren mesleklerden birini yapan, eğitim amaçlarının gerçekleştirilmesinde en stratejik öğe olarak kabul edilen öğretmenler için de önemli ve gereklidir. Toplumun gelişmesi ve kalkınması için en önemli faktör eğitimdir. Eğitim, ürünü insan olan bir hizmet sektörüdür. Bu sektörün en önemli öğesi ise öğretmendir (Adıgüzel ve diğ., 2012 ). Eğitimin verimli olması, toplumun kültür düzeyinin yükseltilmesi bu görevi üstlenmiş olan öğretmenlerin görevlerini severek ve isteyerek yapmaları ile sağlanabilir. Okul açısından bakıldığında Öğretmenler için iş doyumu “öğretmenin öğrencilerine ve okuluna karşı tutu$\mathrm{mu}$ " ya da "öğretmenlerin işlerinden duydukları hoşnutluk ya da hoşnutsuzluk" olarak tanımlanabilir (Vural, 2004: 32). Öğretmenlerin iş doyumu düzeylerinin düşük olması, onların zamanla hayat doyumların da etkilemekte, ruhsal yönden zayıflamalarına neden olabilmektedir. Öğretmenlerin karşılaştıkları olumsuz çalışma koşulları bir süre sonra onların işlerinden aldıkları doyumun düşmesine neden olabilmekte ve bunun sonucunda işe devamsızlıklar başlayabilmekte hatta fırsatını bulabilen öğretmen işini değiştirmektedir (Akçamete ve diğ., 2001).

Eğitim, insanın doğumuyla başlayan ve ömür boyu devam eden bir süreçtir. Bu süreç içeri- sinde coğrafya eğitimi ayrı bir değere sahiptir. Coğrafya dünyayı anlayabilmemiz ve yaşayabilmemiz için bir anahtardır. Coğrafya eğitimi herkes için büyük önem taşımaktadır. Çünkü coğrafya insanların yerküre ve çevreyi tanımalarını sağladığı gibi fiziki coğrafya unsurlarıyla insan hayatının ilişkilerini, kişilerde yurt sevgisi duygusunun gelişip kökleşmesini de sağlayabilmektedir. Günümüz dünyasında yaşanan sorunları anlamada ve çözmede, sürdürülebilir kalkınma sağlamada coğrafyacılar anahtar bir role sahiptir. Çünkü coğrafyanın işlevsellik kazanmasında en önemli boyutunu coğrafya öğretmenleri oluşturmaktadır (Karabağ, 2002). $\mathrm{Bu}$ durumda coğrafya öğretmenlerinin alan bilgisine, pedagojik formasyon bilgisine ve genel kültür bilgisine sahip olmalarının yanında iş doyumlarının da yüksek olması coğrafya eğitiminin kalitesini etkileyebilecektir.

Öğretmenlerin iş doyumlarının çalışma koşulları, bireysel özellikleri ve çeşitli değişkenler açısından incelendiği çok sayıda çalışma bulunmaktadır (Bishay, 1996; Duman, 2006; Crossman ve Harris, 2006; Kale, 2007; Taşdan ve Tiryaki, 2008; Şahin ve Dursun, 2009; Bayhan, 2009; Karataş ve Güleş, 2010; Türkçapar, 2012; Koruklu ve diğ., 2013).

Kaya ve Alım (2015) çalışmalarında coğrafya öğretmenlerinin eğitim-öğretim süreci, öğretmenlik mesleği, kurum (okul), ve kişisel olmak üzere dört farklı kategori, on tema ve yirmi iki alt tema altında birçok stres kaynağından olumsuz yönde etkilendiğini, coğrafya öğretmenlerinin yaşam doyumlarını ortaya koyacak çalışmaların yapılmasının yararlı olabileceğini ifade etmektedir. $\mathrm{Bu}$ bağlamda ülkemizde birçok meslek grubu ve alan öğretmenlerinin iş doyum düzeylerini inceleyen çalışmaların yapılmış olmasına karşılık, coğrafya öğretmenlerinin iş doyum düzeylerini konu edinen Duman (2006)'ın çalışması dışında akademik çalışmalar tespit edilememiştir. $\mathrm{Bu}$ araştırma 
coğrafya öğretmenlerinin iş doyum düzeylerini belirlerken aynı zamanda öğretmenlerin bu doyuma ulaşmaları için beklentilerini ortaya koyması bakımından önem taşımaktadır. Ayrıca özelde coğrafya öğretmenlerinin iş doyum düzeylerinin ortaya konulması genelde öğretmen iş doyumları ile ilişkili olarak okullarda birçok sorunun da çözüme ulaşmasında etkili olabileceği düşünülmektedir. Bu doğrultuda araştırmada amaç coğrafya öğretmenlerinin iş doyum düzeylerini ortaya koymak ve iş doyum düzeylerinin artırılmasına yönelik önerilerde bulunmaktır.

\section{YÖNTEM}

$\mathrm{Bu}$ araştırma, tarama modelinin kullanıldığ betimsel nitelikli bir çalışmadır. Bu model; “geçmişte ya da halen var olan bir durumu var olduğu şekliyle betimlemeyi amaçlayan araştırma yaklaşımıdır. Araştırmaya konu olan olay, birey ya da nesne, kendi koşulları içinde ve olduğu gibi tanımlanmaya çalışılır. Onları, herhangi bir şekilde değiştirme, etkileme çabası gösterilmez" (Karasar, 2009: 77).

\section{1 Çalışma Grubu}

Araştırmanın çalışma evrenini, 2014-2015 eğitim-öğretim yılı bahar döneminde Türkiye'deki devlet ve özel okullarda çalışan coğrafya öğretmenleri; örneklemini ise yine belirtilen dönemde yansız olarak seçilen 324 coğrafya öğretmeni oluşmaktadır. Araştırmaya katılan coğrafya öğretmenlerinin 95'i Kadın, 229'u Erkek; 62'si 24-28 yaş grubu; 99'u 29-33 yaş grubu, 69'u 34-38 yaş grubu; 44'ü 39-43 yaş grubu; 50'si ise 44 ve üzeri yaş grubunda; 226's1 Evli, 98'i Bekar; 25'i Öğretmen Okulu; 272'si Lisans, 27'si Yüksek Lisans Mezunu, 191'i İlde, 121'i İlçede, 12'si diğer yerleşimlerde oturmakta; 76'sı 1-5 yıl arası, 78'i 6-10 yıl arası, 76'sı 1120 yıl arası ve 94'ü ise 21 ve üzeri yıl mesleki kıdeme sahip, 216'sı Devlet Okulunda, 108'i
Özel Okullarda; 179'u Anadolu, 78'i Fen, 30'ü Sosyal Bilimler ve 37'si Meslek Lisesinde çalışmaktadır.

\subsection{Veri Toplama Araçları}

\subsubsection{Kişisel bilgi formu}

Coğrafya Öğretmenlerinin demografik özelliklerini belirlemek amacıyla araştırmacı tarafından geliştirilen "Kişisel Bilgi Formu" kullanılmıştır. Bu form; cinsiyet, yaş, arazi gezi ve inceleme çalışmaları, fiziksel ortam (ders araç gereç) yeterliliği, çalışılan kurum türü, çalışılan okul türü ve Coğrafya Dersi Öğretim Programı (CDÖP )sorularından oluşmaktadır.

\subsubsection{Minnesota iş doyum ölçeği (MiDÖ)}

Coğrafya öğretmenlerinin iş doyumu düzeylerini belirlemek için Minnesota İş Doyum Ölçeğinin (Minnesota Satisfaction Questionnaire) kısa formu kullanılmıştır. Minnesota Doyum Ölçeği'nin uzun formundan (100 madde) iç ve dış faktörlerden oluşan doyum durumları ile ilgili maddeler birleştirilerek 20 madde halinde bir ölçek geliştirilmiştir (Weiss ve diğ., 1967). Baycan (1985) tarafından yapılan geçerlilik ve güvenirlilik çalışmaları sonunda Cronbach Alpha değeri 0.77 olarak bulunmuştur. Genel doyum puanı maddelerin tamamından elde edilen puanların toplamından oluşmaktadır. Buna göre en düşük puan 20, en yüksek puan 100 'dür. Yükselen puanlar iş doyumunun arttığını göstermektedir. Minnesota iş doyum ölçeğindeki puanlar; Hiç hoşnut değilim: 1 puan, Hoşnut değilim: 2 puan, Kararsızım: 3 puan Hoşnutum: 4 puan, Çok Hoşnutum: 5 puan olarak değerlendirilmiştir.

Ölçeğin 12 maddesi içsel faktörlere bağlı iş doyumunu ölçmekte, 8 maddesi de dişsal faktörlere bağlı iş doyumunu ölçmektedir. Ölçeğe ait içsel ve dışsal faktörler birleşik olarak genel iş doyumu olarak ele alınmıştır. Pek çok araştırmada kullanılan ölçeğin, bu araştırmada güvenilirlik katsayısı 0,85 olarak bulunmuştur. 


\subsection{Verilerin toplaması ve analizi}

Araştırmada veriler, araştırmacı tarafından hazırlanan, coğrafya öğretmenlerinin kişisel özelliklerine ve çalışma ortamlarına ilişkin sorulardan oluşan" Kişisel Bilgi Formu" ve "Minnesota İş Doyum Ölçeği" ile elde edilmiştir. Kişisel bilgi formu ve Minnesota İş Doyum Ölçeği internet ortamından Türkiye'nin farklı bölgelerindeki coğrafya öğretmenlerine elektronik ortamda iletilmiş ve dönütler aynı yoldan geri alınmıştır. İlk olarak dönütlerden çıktılar alınıp sıralama yapılmış, tüm dönütler ayrı ayrı değerlendirilip eksik veya yanlış doldurulanlar değerlendirme dışı bırakılmıştır. 17 öğretmenin anketi uygun olmadığı için değerlendirmeye alınmamıştır. Daha sonra, katılımcılardan elde edilen veriler sosyal bilimler için geliştirilmiş olan SPSS istatistik paket programı kullanılarak analiz edilmiştir. Anlamlılık düzeyi .05 olarak kabul edilmiştir. Elde edilen veriler normallik testine tabi tutulduktan sonra, bağımsız iki örneklem grubuna ilişkin ortalamalar arası farkı test etmek için bağımsız örneklem (independent sample) t-testi ve ikiden fazla grup ortalaması arasındaki farkı test etmek için Tek Yönlü Varyans Analizi (ANOVA) kullanılmıştır. Gruplar arası fark çıtı̆̆ında bu farkın kaynağını bulmak için LSD ve Scheffe testlerinden faydalanılmıştır.

\section{BULGULAR}

Araştırma grubundan elde edilen veriler doğrultusunda bulgular tablolaştırılarak aşağıda sunulmuştur.

Tablo 1. Araştırma Grubunun Yaş Değişkenine Göre Analiz Sonuçları

\begin{tabular}{lcccccc}
\hline Ölçek & Yaş & $\mathbf{n}$ & $\overline{\mathbf{X}}$ & $\mathbf{S s}$ & $\mathbf{F}$ & $\mathbf{p}$ \\
\hline \multirow{4}{*}{ İçsel doyum } & $24-28$ & 62 & 3.93 & .51 & & \\
& $29-33$ & 99 & 3.83 & .60 & & \\
& $34-38$ & 69 & 3.89 & .54 & .990 & .413 \\
& $39-43$ & 44 & 3.77 & .58 & & \\
Dişsal doyum & 44 ve üzeri & 50 & 3.75 & .61 & & \\
& $24-28$ & 62 & 3.35 & .65 & & \\
& $29-33$ & 99 & 3.18 & .66 & & \\
& $34-38$ & 69 & 3.22 & .72 & .803 & \\
Genel doyum & $39-43$ & 44 & 3.13 & .78 & & \\
& 44 ve üzeri & 50 & 3.26 & .70 & & \\
& $24-28$ & 62 & 3.70 & .49 & & \\
& $29-33$ & 99 & 3.57 & .56 & & \\
& $34-38$ & 69 & 3.62 & .52 & .961 & \\
& $39-43$ & 44 & 3.51 & .58 & & \\
\hline
\end{tabular}

${ }^{*} \mathrm{p}<0.05$

Tablo 1 'de görüldüğü gibi araştırma grubunun yaş değişkenine göre içsel iş doyum, dışsal iş doyum ve genel iş doyum puan ortalamaları arasında istatistiksel olarak anlamlı bir fark olmadı̆̆ tespit edilmiştir ( $\mathrm{p}>0.05)$. Fakat her bir iş doyum boyutunda da en yüksek iş doyum puan ortalamalarına sahip olanların 24-28 yaş aralığında olan coğrafya öğretmenlerinin olduğu görülmektedir. 
Tablo 2. Araştırma Grubunun Cinsiyet Değişkenine Göre Analiz Sonuçları (t-test)

\begin{tabular}{|c|c|c|c|c|c|c|}
\hline Ölçek & Cinsiyet & $\mathrm{n}$ & $\overline{\mathrm{X}}$ & Ss & $\mathrm{t}$ & $\mathrm{p}$ \\
\hline \multirow{2}{*}{ İçsel doyum } & Erkek & 229 & 3.82 & .58 & \multirow{2}{*}{-.933} & \multirow{2}{*}{.352} \\
\hline & Kadın & 95 & 3.89 & .54 & & \\
\hline \multirow{2}{*}{ Dişsal doyum } & Erkek & 229 & 3.25 & .70 & \multirow{2}{*}{.710} & \multirow{2}{*}{.478} \\
\hline & Kadın & 95 & 3.18 & .67 & & \\
\hline \multirow{2}{*}{ Genel doyum } & Erkek & 229 & 3.59 & .55 & \multirow{2}{*}{-.224} & \multirow{2}{*}{.823} \\
\hline & Kadın & 95 & 3.61 & .54 & & \\
\hline
\end{tabular}

${ }^{*} \mathrm{p}<0.05$

Tablo 2‘de görüldüğü gibi araştırma grubunun cinsiyet değişkenine göre içsel iş doyum, dişsal iş doyum ve genel iş doyum puan ortalamaları arasında istatistiksel olarak anlamlı bir fark olmadığ1 tespit edilmiştir $(p>0.05)$. İçsel ve

Tablo 3. Araştırma Grubunun Arazi Gezi ve İnceleme Çalışmaları Durumu Değişkenine Göre Analiz Sonuçları

\begin{tabular}{|c|c|c|c|c|c|c|c|}
\hline Ölçek & Gezi inceleme & $\mathrm{n}$ & $\overline{\mathrm{X}}$ & Ss & $\mathrm{F}$ & $\mathrm{p}$ & Fark LSD \\
\hline \multirow{3}{*}{ İçsel doyum } & 1. Yeterli & 65 & 4.04 & .47 & \multirow{3}{*}{8.492} & \multirow{3}{*}{$.000^{*}$} & \multirow{3}{*}{$1>2.3$} \\
\hline & 2. Kismen yeterli & 171 & 3.73 & .59 & & & \\
\hline & 3. Yetersiz & 88 & 3.92 & .55 & & & \\
\hline \multirow{3}{*}{ Dişsal doyum } & 1. Yeterli & 65 & 3.35 & .82 & \multirow{3}{*}{1.491} & \multirow{3}{*}{.227} & \\
\hline & 2. Kismen yeterli & 171 & 3.18 & .64 & & & \\
\hline & 3. Yetersiz & 88 & 3.23 & .69 & & & \\
\hline \multirow{3}{*}{ Genel doyum } & 1. Yeterli & 65 & 3.77 & .53 & \multirow{3}{*}{5.836} & \multirow{3}{*}{$.003^{*}$} & \multirow{3}{*}{$1>2.3$} \\
\hline & 2. Kismen yeterli & 171 & 3.51 & .54 & & & \\
\hline & 3. Yetersiz & 88 & 3.64 & .52 & & & \\
\hline
\end{tabular}

${ }^{*} \mathrm{p}<0.05$

Tablo 3 'de görüldüğü gibi araştırma grubunun arazi gezi ve inceleme çalışmaları yapabilme durumu değişkenine göre içsel iş doyum ve genel iş doyum puan ortalamaları arasında istatistiksel olarak anlamlı fark olduğu, dışsal iş doyum puan ortalamaları arasında ise anlamlı

Tablo 4. Araştırma Grubunun Fiziksel Ortam (Ders Araç Gereç Durumu) Değişkenine Göre Analiz

\begin{tabular}{|c|c|c|c|c|c|c|c|}
\hline \multicolumn{8}{|c|}{ Sonuçları } \\
\hline Ölçek & Ders Araç-Gereç & $\mathrm{n}$ & $\overline{\mathrm{X}}$ & Ss & $\mathrm{F}$ & $\mathrm{p}$ & Fark LSD \\
\hline \multirow{3}{*}{ İçsel doyum } & 1. Yeterli & 108 & 3.95 & .52 & \multirow{3}{*}{3.569} & \multirow{3}{*}{$.029^{*}$} & \multirow{3}{*}{$1>2.3$} \\
\hline & 2. Kismen yeterli & 138 & 3.76 & .63 & & & \\
\hline & 3. Yetersiz & 78 & 3.83 & .50 & & & \\
\hline \multirow{3}{*}{ Dişsal doyum } & 1. Yeterli & 108 & 3.36 & .73 & \multirow{3}{*}{3.925} & \multirow{3}{*}{$.021^{*}$} & \multirow{3}{*}{$\begin{array}{c}1>2.3 \\
2>3\end{array}$} \\
\hline & 2. Kismen yeterli & 138 & 3.20 & .65 & & & \\
\hline & 3. Yetersiz & 78 & 3.08 & .70 & & & \\
\hline
\end{tabular}

genel iş doyum boyutunda Kadın coğrafya öğretmenlerinin; dişsal iş doyum boyutunda ise Erkek coğrafya öğretmenlerinin iş doyum puan ortalamaları daha yüksektir. 


\begin{tabular}{llcccccc}
\hline & 1. Yeterli & 108 & 3.72 & .50 & & & \\
Genel doyum & 2. Kismen yeterli & 138 & 3.54 & .57 & 4.085 & $.018^{*}$ & $1>2.3$ \\
& 3. Yetersiz & 78 & 3.53 & .53 & & & \\
\hline${ }^{*} \mathrm{p}<0.05$ & & & & & &
\end{tabular}

Tablo 4 'de görüldüğü gibi araştırma grubunun fiziksel ortam (ders araç gereç durumu) değişkenine göre içsel, dışsal ve genel iş doyum puan ortalamaları arasında istatistiksel olarak

anlamlı fark olduğu tespit edilmiştir. İş doyumunun her bir alt boyutta da yeterli iş doyuma ulaştıklarını ifade eden öğretmenler lehine olduğu belirlenmiştir.

Tablo 5. Araştırma Grubunun Çalışılan Kurum Değişkenine Göre Analiz Sonuçları

\begin{tabular}{|c|c|c|c|c|c|c|}
\hline Ölçek & Çalışılan kurum & $\mathrm{n}$ & $\overline{\mathrm{X}}$ & Ss & $t$ & $\mathrm{p}$ \\
\hline \multirow{2}{*}{ İçsel doyum } & Devlet okulu & 216 & 3.89 & .58 & \multirow{2}{*}{2.105} & \multirow{2}{*}{$.036^{*}$} \\
\hline & Özel okul & 108 & 3.75 & .53 & & \\
\hline \multirow{2}{*}{ Dişsal doyum } & Devlet okulu & 216 & 3.27 & .68 & \multirow{2}{*}{1.537} & \multirow{2}{*}{.125} \\
\hline & Özel okul & 108 & 3.14 & .72 & & \\
\hline \multirow{2}{*}{ Genel doyum } & Devlet okulu & 216 & 3.64 & .54 & \multirow{2}{*}{2.110} & \multirow{2}{*}{$.036^{*}$} \\
\hline & Özel okul & 108 & 3.51 & .54 & & \\
\hline
\end{tabular}

${ }^{*} \mathrm{p}<0.05$

Tablo 5 'de görüldüğü gibi araştırma grubunun ortaöğretimde çalışılan kurum değişkenine göre içsel iş doyum ve genel iş doyum puan ortalamaları arasında istatistiksel olarak anlamlı fark olduğu, dışsal iş doyum puan ortalama- ları arasında ise anlamlı bir farkın olmadı ̆̆ 1 tespit edilmiştir. Her iki iş doyum puan ortalamaları arasındaki farkın devlet okullarında çalıştıklarını ifade eden coğrafya öğretmenleri lehine olduğu görülmüştür.

Tablo 6. Araştırma Grubunun Çalışılan Okul Türü Değişkenine Göre Analiz Sonuçları

\begin{tabular}{|c|c|c|c|c|c|c|c|}
\hline Ölçek & Çalışılan okul & $\mathrm{n}$ & $\overline{\mathrm{X}}$ & Ss & $\mathrm{F}$ & $\mathrm{p}$ & Scheffe \\
\hline \multirow{4}{*}{ İçsel doyum } & 1. Anadolu Lisesi & 179 & 3.92 & .56 & \multirow{4}{*}{3.081} & \multirow{4}{*}{$.028^{*}$} & \\
\hline & 2. Fen Lisesi & 78 & 3.74 & .48 & & & $1>2.3 .4$ \\
\hline & 3. Sosyal bilimler Lisesi & 30 & 3.80 & .67 & & & $3>4$ \\
\hline & 4. Meslek Lisesi & 37 & 3.69 & .65 & & & \\
\hline \multirow{4}{*}{ Dişsal doyum } & 1. Anadolu Lisesi & 179 & 3.32 & .65 & \multirow{4}{*}{2.302} & \multirow{4}{*}{.077} & \\
\hline & 2. Fen Lisesi & 78 & 3.11 & .71 & & & \\
\hline & 3. Sosyal bilimler Lisesi & 30 & 3.17 & .84 & & & \\
\hline & 4. Meslek Lisesi & 37 & 3.09 & .69 & & & \\
\hline \multirow{4}{*}{ Genel doyum } & 1. Anadolu Lisesi & 179 & 3.68 & .51 & \multirow{4}{*}{3.545} & \multirow{4}{*}{$.015^{*}$} & \\
\hline & 2. Fen Lisesi & 78 & 3.49 & .50 & & & $1>2.4$ \\
\hline & 3. Sosyal bilimler Lisesi & 30 & 3.54 & .69 & & & $3>4$ \\
\hline & 4. Meslek Lisesi & 37 & 3.45 & .59 & & & \\
\hline
\end{tabular}

${ }^{*} \mathrm{p}<0.05$

Tablo 6'de görüldüğü gibi araştırma grubunun ortaöğretimde çalışılan okul türü değişkenine göre içsel iş doyum ve genel iş doyum puan ortalamaları arasında istatistiksel olarak anlamlı fark olduğu, dişsal iş doyum puan ortalamaları arasında ise anlamlı bir farkın olmadığ 
tespit edilmiştir. İçsel ve genel iş doyum puan ortalamaları arasındaki farkın Anadolu Lisele- rinde çalıştıklarını ifade eden coğrafya öğretmenleri lehine olduğu belirlenmiştir.

Tablo 7. Araştırma Grubunun Coğrafya Dersi Öğretim Programı (CDÖP) Değişkenine Göre Analiz Sonuçları

\begin{tabular}{llccccc}
\hline Ölçek & CDÖP & $\mathrm{n}$ & $\overline{\mathrm{X}}$ & Ss & $\mathrm{F}$ & $\mathrm{p}$ \\
\hline \multirow{3}{*}{ İçsel doyum } & Uygun & 108 & 3.85 & .53 & & \\
& Sorunlu & 161 & 3.85 & .57 & .148 & .863 \\
& Uygun değil & 55 & 3.80 & .65 & & \\
\hline \multirow{3}{*}{ Dişsal doyum } & Uygun & 108 & 3.24 & .72 & & \\
& Sorunlu & 161 & 3.24 & .71 & .259 & .772 \\
& Uygun değil & 55 & 3.17 & .60 & & \\
\hline \multirow{3}{*}{ Genel doyum } & Uygun & 108 & 3.60 & .53 & & \\
& Sorunlu & 161 & 3.61 & .55 & .251 & .778 \\
& Uygun değil & 55 & 3.55 & .55 & & \\
${ }^{*}{ }^{*}<0.05$ & & & & & &
\end{tabular}

Tablo 7 'de görüldüğü gibi araştırma grubunun Coğrafya Dersi Öğretim Programı (CDÖP) arasında istatistiksel olarak anlamlı bir fark değişkenine göre içsel iş doyum, dışsal iş doyum ve genel iş doyum puan ortalamaları olmadığ 1 tespit edilmiştir. Her bir iş doyum boyutunda birbirine yakın puan ortalamalarının olduğu görülmektedir.

Tablo 8. Araştırma grubunun genel iş doyum düzeylerine ait ortalama sonuçları

\begin{tabular}{cccccc}
\hline & $\mathrm{n}$ & Minimum & Maximum & Ortalama & Ss \\
\hline Genel İş doyum Düzeyi & 324 & 2.00 & 4.85 & 3.60 & .54 \\
\hline
\end{tabular}

Tablo 8 'de görüldüğü gibi araştırma grubunun genel iş doyum düzeylerine ait ortalamaları $=3,60$ olarak belirlenmiştir. Bu kullanılan iş doyum ölçeğinin puan aralıklarına göre "Orta doyumlu" olarak ifade edilmektedir.

\section{SONUÇ VE TARTIŞMA}

Öğretmenlerin kişisel sağlı̆̆ı, yaşamında mutlu olması haz alabilmesi çalıştı̆̆ı kuruma yararlı olabilmesi için yaptığı işten doyum sağlaması oldukça önemlidir. Araştırma grubunu oluşturan coğrafya öğretmenlerinin genel iş doyumu "Orta doyumlu" (Ortalama =3,60) düzeyinde belirlenmiştir (Tablo.8). Bu durum, alanda yapılan bazı çalışmalarla tutarlılık göstermektedir (Crossman ve Harris, 2006; Taşdan ve
Tiryaki, 2008, Bayhan, 2009; Demirtaş ve Ersözlü, 2010; Altınkurt ve Yılmaz, 2014; Buluç ve Demir, 2015) Köklü (2012)'nün ortaöğretim kurumlarında yaptığı çalışmada ise katılımcıların iş doyum düzeyleri "düşük" seviyede bulunmuştur. Öğretmenlerin iş doyumu düzeylerinin araştırıldığı çalışmalarda doyum düzeylerinin çok yüksek olmadığ (kısmen ya da orta) belirtilmektedir. Hem öğretmenlik hem de coğrafya bilimi adına araştırmada kullanılan iş doyum ölçeğinden alınabilecek en düşük ve en yüksek puan ortalamalarına göre "Orta doyumlu" olarak bulunan sonuç coğrafya öğretmenlerinin iş doyum düzeylerinin artırılmasına yönelik çalışmaların yapılmasının gerekliliğini ortaya koymaktadır. Buna karşılık yapılan bazı çalışmalarda da öğretmenlerin iş doyum sevi- 
yelerinin yüksek çıktı̆̆g görülmektedir (Kağan, 2010; Zöğ, 2007). Çalışmalarda farklı sonuçların ortaya konulmuş olması, öğretmenlerin iş doyumlarının çalıştıkları farklı örgütlerden, farklı kültürlerden ve farklı değişkenlerden etkilenmelerinden kaynaklanmış olabilir. Öğretmenlerin düşük düzeyde doyuma sahip olmaları durumunda hem kendileri, hem öğrencileri ve hem de okulları yararına çalışma isteklerinin olmayacağı; yüksek düzeyde doyuma sahip olmaları durumunda ise onların mesleklerine karşı olumlu tutumda, daha istekli ve verimli olacakları söylenebilir.

Katılımcıların yaş değişkenine göre her üç iş doyum puan ortalamaları arasında istatistiksel olarak anlamlı bir fark olmadığ Elde edilen sonuçların bu alanda yapılan çalışmalar ile benzer sonuçlar verdiği görülmektedir (Değirmenci, 2006; Gülay, 2006; Akçamete ve diğ, 2001; Şahin ve Dursun, 2009; Kale, 2007; Türkçapar, 2012; Duman, 2006). Böyle bir sonucun çıkması özellikle öğretmenlik mesleğinde herhangi bir değişim ve beklentinin olmamasindan ve farklı yaşlara sahip öğretmenlerin iş doyumu ölçeğindeki ifadeleri benzer biçimde algılamış olduklarından kaynaklanmış olabileceği söylenebilir. Zöğ (2007) ve Bayhan (2009)'ın çalışmalarında ise sınıf öğretmenlerinin iş doyumlarının, yaşlarına göre farklılık gösterdiği, mesleğe yeni başlamış genç öğretmenlerin, iş doyumlarının diğer öğretmenlere göre daha düşük olduğu görülmüştür. İnsanların iş doyumlarının 30'lu yaşlarda başarılarının artmasıyla birlikte arttığı, 40'lı yaşlarda düştüğü ve 50'liyaşlarda tekrar arttığı bildirilmiştir (Spector, 1997). Balcı (1985)'ya göre yaş ve iş doyumu arasındaki bu ilişki tutarlı görülmemektedir. Bununla birlikte iş doyumunda yaş değişkeninin etkisinin, kısmen yaşla birlikte artan gelir, yetki, özerklik ve mesleki saygınlık gibi işin dışsal yararları ile açıklanabileceğine yer verilmiştir (Akçamete ve diğ, 2001).
Araştırma grubunun cinsiyet değişkenine göre her üç iş doyum puan ortalamaları arasında istatistiksel olarak anlamlı bir fark olmadığı, erkek ve kadın coğrafya öğretmenlerinin aynı düzeyde iş doyumuna sahip oldukları görülmektedir. $\mathrm{Bu}$ durumda cinsiyetin iş doyum üzerinde etkili olmadığı ifade edilebilir. Araştırma bu alanda yapılan çalışmalar ile benzer sonuçlar göstermektedir (Şahin ve Dursun, 2009; Kale, 2007; Değirmenci, 2006; Zöğ, 2007; Siripak, 2006; Taşdan ve Tiryaki, 2008; Kağan, 2010; Aydemir ve diğ, 2014; Çetinkanat, 2000; Koruklu ve diğ; 2013; Gülay, 2006; Demirtaş ve Ersözlü, 2010; Bayhan, 2009).Öğretmenlik mesleğinde kadın ve erkeklere benzer olanaklar sunulması ve işlerin standartlaştırılmış olması ile okullarda iş doyumunu etkileyebilecek unsurların bütün öğretmenler için aynı şekilde algılanması ve her iki cinsin eşit oranda çalışma hayatında yer alması iş doyum düzeyleri açısından farkl1lık yaşanmamasına neden olabilir.

Zöğ (2007)'ın çalışmasında erkek öğretmenlerin kadın öğretmenlere göre iş doyumlarının daha yüksek olduğu; Duman (2006)'ın çalışmasında ise kadın öğretmenlerin erkek öğretmenlerden daha fazla iş doyumu yaşadıkları belirtilmiştir. İş doyumu ile cinsiyet arasındaki ilişkilerle ilgili çalışmaların birbiriyle tutarlı sonuçlar doğurmadığı görülmektedir. Bu durumda iş doyumu üzerinde cinsiyet değişkeninin iş doyumunun tek belirleyicisi olamayacağı, başka değişkenlerle birleştiğinde etkili olabileceği ya da kadın ve erkek ayrımından çok beklenti düzeyiyle ilgili olduğu söylenebilir.

Coğrafya eğitim ve öğretiminde ezberden uzak yapılandırmacı yaklaşım içinde yapılan arazi gezileri, saha çalışmaları son derece önemli bir yere sahiptir. Sahada olmak, doğa ile iletişim içinde bulunmak öğrencilerin açık hava ile olan temasları, hem onların hem de öğretmenlerin motivasyonlarını arttıracaktır. Lonergan ve Andresen (1988) saha çalışmasını “Dört duvar 
arasındaki sınıf ortamı dışında herhangi bir saha ya da bölgede bir konuda öğrenme ilk elden tecrübe yolu ile gerçekleşir."şeklinde tanımlamaktadır (Akt. Kent ve diğ., 1997). Fen derslerinde laboratuar uygulamaları yapılmadan konular istenilen düzeyde öğretilemiyor ve öğrenilemiyorsa, coğrafya konuları da dış ortamda gözlenip incelenmezse yetersiz kalacaktır. Katılımcıların arazi gezi ve inceleme çalışmaları durumu değişkenine göre içsel iş doyum ve genel iş doyum puan ortalamaları arasında istatistiksel olarak anlamlı fark olduğu, dışsal iş doyum puan ortalamaları arasında ise anlamlı bir farkın olmadığı belirlenmiştir (Tablo.3).Yeterli düzeyde arazi gezi ve inceleme çalışmaları yapabilen öğretmenlerin iş doyum puanları yüksek bulunmuştur. Özgen (2011)'in çalışmasında öğrencilerin fiziki coğrafya konularında arazi gezilerine katılan grubun daha başarılı olduğu istatistiksel olarak belirlenmiştir. Coğrafi araştırmaların laboratuvarı coğrafi mekânın kendisidir. Arazi çalışmaları ile öğrenciler olay ve olgular arasında ilişkiler kuracak, doğal ve beşeri ortamdaki farklılık ve benzerlikleri daha kolay fark edebilecek, analiz ve sonuçlar üretebilecektir. Böylece, kısa ya da uzun süreli geziler ile coğrafi bakış açısı gelişmiş ve yaşadığı ortama duyarlı bireyler yetiştirebilecek olan coğrafya öğretmenlerinin iş doyum düzeyleri artacaktır.

İş doyumunun birçok etkeninden biri de işin yapıldığı fiziksel çevredir. Bir bütün olarak fiziksel çevre çalışma ortamını oluşturmaktadır. Fiziksel çalışma ortamı, maddi unsur olarak çalışanın iş gördüğü ve temas edebileceği yerlerin bütünüdür (Sapancalı, 1993). Gelişen dünyada öğretim araç ve gereçleri öğretmenlerin öğrenme ortamlarını etkin kullanmalarını sağlamak ve iyi bireyler yetiştirmeleri için büyük önem taşımaktadır. Bu durum coğrafya öğretimi alanında çok daha yüksek bir değere sahiptir. Çünkü günümüzdeki gelmiş olduğu seviyesi ile modern coğrafyanın sınıfa yansıtı- labilmesi gerekmektedir. Bunun için de yeryüzünün tamamına veya bir kısmına ait çeşitli bilgilerin güncel olarak istenildiği durumda sınıfa taşınması Coğrafi Bilgi Sistemleri (CBS), küresel konumlama sistemi (GPS) ve Google Earth'ün birlikte kullanılması ile gerçekleştirilen etkinliğin coğrafya dersleri için faydalı olabileceği belirtilmektedir (Demirci ve Karaburun, 2011). Ayrıca coğrafya akıllı tahta sistemlerinin sunduğu firsatlardan yararlanmaya en uygun eğitim branşlarından birisidir. Görselliğin son derece önemli olduğu coğrafya derslerinde harita, tablo ve grafik şeklindeki görsellerin bilgisayar, projektör, internet gibi birçok teknolojik materyalin kullanılması ve aktif bir eğitim ortamının oluşması gerekmektedir. Araştırmada da ders araç gereç durumu değişkenine göre her üç iş doyum puan ortalamaları arasında istatistiksel olarak anlamlı fark olduğu belirlenmiştir (Tablo.4). Bu durum fiziksel olanakların yeterli olduğu okullarda çalışan coğrafya öğretmenlerinin iş doyum düzeylerinin daha yüksek olduğu şeklinde ifade edilebilir. Araştırma bu alanda yapılan çalışmalar ile benzer sonuçlar göstermektedir ( Şahin ve Dursun, 2009; Koruklu ve diğ., 2013; Bayhan,2009; Karademir,2010 ).

Araştırma grubunun çalışılan kurum türü değişkenine göre içsel iş doyum ve genel iş doyum puan ortalamaları arasında istatistiksel olarak anlamlı fark olduğu, dişsal iş doyum puan ortalamaları arasında ise anlamlı bir farkın olmadığı belirlenmiştir. İş doyum puan ortalamaları arasındaki farkın ise devlet okullarında çalıştıklarını ifade eden coğrafya öğretmenleri lehine olduğu görülmektedir (Tablo.5). Katılımcıların büyük bir bölümü devlet okullarında çalışmaktadır. Devlet okullarında çalışan coğrafya öğretmenlerinin iş doyumlarının daha iyi olması, özel okullarda öğretmen açı̆̆ını kapatmak amacıyla sözleşmeli öğretmenlik uygulamasının yapılıyor olması ve çalışma şartlarının yoğunluğu ile devlet okullarının 
özel okullara göre iş güvencesi (devlet memuru garantisi) sağlamış olmasından kaynaklanmış olabilir. Türkçapar (2012) ve Değirmenci (2006)'nin çalışmasında özel liselerde görev yapan öğretmenler ile devlet liselerinde görev yapan öğretmenlerin iş doyum düzeylerini okul türünün etkilemediği yönünde bulgular elde edilmiştir. Bazı çalışmalarda ise özel okulda çalışanların iş doyumlarının devlet okulunda çalışanlara göre daha yüksek olduğu ifade edilmiştir (Karaköse ve Kocabaş, 2006; Taşdan ve Tiryaki, 2008; Kağan, 2010) .

Araştırma grubunun çalışılan okul türü değişkenine göre içsel iş doyum ve genel iş doyum puan ortalamaları arasında istatistiksel olarak anlamlı fark olduğu, dişsal iş doyum puan ortalamaları arasında ise anlamlı bir farkın olmadığı belirlenmiştir. Anadolu Liselerinde çalışan coğrafya öğretmenlerinin daha fazla iş doyumuna ulaştıkları görülmektedir (Tablo.6). Anadolu liselerinde coğrafya derslerinin ders saatlerinin daha fazla olması, fen liseleri ve meslek liselerinde ise daha az olması bu duruma neden olmuş olabilir. Araştırmada okul türü değişkenine göre coğrafya öğretmenleri arasında dışsal iş doyum puan ortalamaları arasında ilişkinin çıkmamış olması ise iş doyumunun yalnızca meslek ve iş koşullarıyla açıklanamayacak kadar karmaşık bir kavram olmasıyla açıklanabilir. Aydemir ve diğ., (2014)'nin çalışmasında öğretmenlerin, çalışmakta oldukları okul türünün her üç değişkene göre de iş doyumlarının anlamlı düzeyde farklılaşmadığı ifade edilmiştir. Adıgüzel ve diğ., (2012)'nın çalışmasında görev yapılan okul türüne göre dişsal iş doyum puanları arasında anlamlı farklılık olduğu; Altınkurt ve Yılmaz (2014)'ın çalışmasında ise görev yapılan okul türüne göre en yüksek ortalamaya okul öncesi öğretmenlerinin, en düşük ortalamaya ise meslek lisesi, ilkokul ve ortaokul öğretmenlerinin sahip oldukları ifade edilmiştir.
Bazı çalışmalarda coğrafya öğretmenlerinin klasik eğitim modeliyle yetişmiş olmaları ve uzun yıllardır bu modelle öğretim sürecini gerçekleştirmeleri, bir kısmının yapısalcı eğitim modeline karşı direndikleri, coğrafya dersi öğretim programı yaklaşımlarına aykırı uygulamaları sürdürdükleri ve gelenekçi (klasik) eğitim anlayışını devam ettirdikleri ifade edilmektedir (Geçit, 2008; Öztürk ve Eroğlu, 2013). Erdoğan ve diğ., (2015)'nin çalışmasında ise ilerleyen süreçte öğretmenlerin zamanla ve uyguladıkça öğretim programını daha iyi tanımış ve anlamış olmaları nedeniyle olumlu görüş sunmaya başladıkları belirtilmektedir. Araştırmada Coğrafya Dersi Öğretim Programı değişkenine göre iş doyum puan ortalamaları arasında istatistiksel olarak anlamlı bir fark olmadığı belirlenmiştir (Tablo.7). Bu durumda coğrafya öğretmenlerinin Coğrafya Dersi Öğretim Programına bakış açılarının iş doyum düzeylerini etkilemediği şeklinde ifade edilebilir. Akademik çalışmalarda öğretim programlarına ilişkin bir değerlendirme ile iş doyumu konusunda yeterli ölçüde bir çalışmaya rastlanmamiştır. Koruklu ve diğ., (2013)'ın çalışmasında ise yenilenen ortaöğretim ders programına ilişkin öğretmen görüşlerine göre iş doyumunda anlamlı farklılık görülmüş, yeni ortaöğretim programını uygun bulanların iş doyumlarının daha yüksek olduğu belirtilmiştir.

\section{5. ÖNERİLER}

Araştırma sonuçlarına göre şu önerilerde bulunulabilir. Ortaöğretim kurumlarında coğrafya laboratuvarları ve dersliklerde akıllı tahtaların bulunuyor ve kullanılabiliyor olmaları sağlanabilir. Coğrafya ders saatleri arttırılabilir. Coğrafya öğretmenlerinin iş doyum düzeyleri üzerindeki çalışmalar daha geniş kapsamlı gruplarla ve farklı coğrafi bölgeler bazında karşılaştırmalı olarak sürdürülebilir. Bunun dışında coğrafya öğretmelerinin diğer alan 
öğretmenleriyle iş doyum düzeyleri karşılaşt1rılarak, olası farklılıklar belirlenip, bu farklılıkların nedenleri araştırılabilir. Arazi gezilerinin daha sık uygulanması, bireysel çabalar ile değil sistemli bir biçimde gezilerin organize edilmesi ve coğrafya dersi öğretim programlarında uygulamalı coğrafya derslerinin (Arazi gezileri ve gözlemler) kullanılmasına teşvik edilmesi sağlanabilir. Bu önerilerin gerçekleşmesi durumunda coğrafya öğretmenlerinin iş doyumlarının artacağı ve gelecek nesillerimize daha çă̆daş ve kaliteli bir eğitim anlayışı sunabilecekleri düşünülmektedir.

\section{Kaynakça}

Adıgüzel, Z., Karadağ, M. ve Ünsal, Y. (2012). Fen ve Teknoloji Öğretmenlerinin İş Tatmin Düzeylerinin Bazı Değişkenlere Göre İncelenmesi. Batı Anadolu Ĕ̆itim Bilimleri Dergisi, 2(4), 49-74.

Agho, A. O., Mueller, C. W. ve Price, J. L. (1993). Determinants of employee job satisfaction: An empirical test of a causal model. Human Relations, 46, 1007-1027.

Akçamete, G., Kaner, S ve Sucuoğlu, B. (2001).Öğretmenlerde Tükenmişlik, Işs Doyumu ve Kişilik. Nobel Yayınları. Ankara.

Altınkurt, Y. ve Yılmaz, K. (2014). Öğretmenlerin Mesleki Profesyonelliği İle İş Doyumları Arasındaki İlişki, Sakarya University Journal of Education, 4(2), 57-71.

Aydemir, H., Diken, İ., K., Yıkmış, A., Aksoy, V. ve Özokçu, O. (2014). Özel eğitim alanında çalışan öğretmenlerin tükenmişlik düzeyleri ve yaşam doyumlarının incelenmesi. Abant İzet Baysal Üniversitesi Ĕ̆itim Fakültesi Dergisi, 15(Özel Sayı), 68-86.

Balcı, A. (1985). Ĕ̆itim Yöneticisinin İş Doyumu. Yayımlanmamış Doktora Tezi. Ankara Üniversitesi.

Baycan, A. (1985). “An Analysis Of The Several Aspects Of Job Satisfaction Between Different Occupational Groups", Boğaziçi Üniversitesi SBE Doktora Tezi, İstanbul.

Bayhan, P. (2009). İlköğretim Okulları Birinci Kademe Sınıf Öğretmenlerinin Öğretmenlik Mesleğine Yönelik Tutumları İle İş Doyumları Arasındaki İlişki, Yeditepe Üniversitesi Sosyal Bilimler Enstitüsü, (Yayımlanmamış Yüksek Lisans Tezi), İstanbul.

Bishay, A. (1996). Teacher Motivation And Job Satisfaction: A Study Employing The Experience Sampling Method. J Undergrad. Sci, 3, 147-154.

Buluç, B. ve Demir, S. (2015). İlk ve Ortaokul Öğretmenlerinin Öz-Yeterlik Algıları ile İş Doyumları Arasındaki İlişki, Ahi Evran Üniversitesi Kırşehir Eğitim Fakültesi Dergisi (KEFAD), 16(1), 289-308.

Crossman, A. ve Harris, P. (2006). Job Satisfaction of Secondary School Teachers. EducationalManagement Administration and Leadership, 34, 29-46.

Çetinkanat, C. (2000). Örgütlerde Güdülenme ve İş Doyumu. Anı Yayıncılık. Ankara.

Değirmenci, S. (2006). Lise Yöneticilerinin Kültürel Liderlik Rollerinin Öğretmenlerin İş Doyumuna Etkisi.(Yayımlanmamış Yüksek Lisans Tezi). Abant İzzet Baysal Üniversitesi Sosyal Bilimler Enstitüsü, Bolu. 
Demirci, A ve Karaburun, A. (2011). CBS, GPS VE GOOGLE EARTH Teknolojilerinin Coğrafya Derslerinde Kullanımı. Marmara Coğrafya Dergisi, 24, 99-123.

Demirtaş, Z. ve Ersözlü, A. (2010). Liselerde Görev Yapan Öğretmenlerin İş Doyumu Düzeyleri. eJournal of New World Sciences Academy Education Sciences, 5(1), 199-209.

Duman, C. (2006).Ortaöğretim Kurumlarında Görev Yapan Coğrafya Öğretmenlerinin İş Tatmini, Yayınlanmamış Yüksek Lisans Tezi Marmara Üniversitesi Eğitim Bilimleri Enstitüsü, İstanbul.

Erdoğan, M., Kayır, Ç.G., Kaplan, H., Aşık, Ü.Ö. ve Akbunar, Ş .(2015). 2005 Yılı Ve Sonrasında Geliştirilen Öğretim Programları İle İlgili Öğretmen Görüşleri; 2005-2011 Yılları Arasında Yapılan Araştırmaların İçerik Analizi, Kastamonu Eğitim Dergisi, 23(1), 171- 196.

Geçit, Y. (2008). Cumhuriyet dönemi lise coğrafya öğretim Programları üzerinde bir çalışma, Marmara Coğrafya Dergisi. 18, 149-178.

Gülay, H.E. (2006). Beden Eğitimi Öğretmenlerinin İş Doyum Düzeylerinin Araştırllması (Kocaeli İli örneği). Yayınlanmamış Yüksek Lisans Tezi, Sakarya Üniversitesi, Sakarya.

Kağan, M. (2010). Ankara İlindeki Devlet Ve Özel İlköğretim okulları İle Rehberlik Ve Araştırma Merkezlerinde Çalışan Rehber Öğretmenlerin İş Doyumlarının İncelenmesi, Erzincan Eğitim Fakültesi Dergisi, 12(1), 39-55

Kale, F. (2007). Beden Eğitimi Öğretmenlerinin İş Doyumu Ve Tükenmişlik Düzeylerinin Çeşitli Değişkenler Açısından İncelenmesi, Yayınlanmamış Yüksek Lisans Tezi, Niğde Üniversitesi Sosyal Bilimler Enstitüsü Beden Eğitimi Ve Spor Anabilim Dalı, Niğde.

Karabağ, S. (2002). Coğrafya Öğretmenlerinin Mesleki Nitelikleri. Türk Coğrafya Kurumu Coğrafya Kurultayı, Bildiriler Kitabl, Gazi Kitapevi, Ankara.

Karademir, T. (2010). Beden Eğitimi Öğretmenlerinin Örgütsel Adalet Algıları Ve İş Doyum Düzeylerinin Değerlendirilmesi, e-Journal of New World Sciences AcademySports Sciences, 5(2), 88-103.

Karataş, S. ve Güleş, H. (2010). İlköğretim Okulu Öğretmenlerinin İş Tatmini İle Örgütsel Bağlllığı Arasındaki İlişki. Uşak Üniversitesi Sosyal Bilimler Dergisi, 3(2), 74-89.

Karaköse, T. ve Kocabaş, İ. (2006). Özel ve Devlet Okullarında Öğretmenlerin Beklentilerinin İş Doyumu ve Motivasyon Üzerine Etkileri, Eğitimde Kuram ve Uygulama, 2(1), 3-14.

Karasar, N. (2009). Bilisel Araştırma Yöntemleri. Ankara: Nobel Yayın Dağıtım.

Kaya, M. F. ve Alım, M. (2015 ). Coğrafya Öğretmenlerinin Stres Kaynakları Üzerine Bir Araştırma, Doğu Coğrafya Dergisi, 20(34), 171-186.

Kent, M., Gilbertson D.D. ve Hunt, C.O. (1997). Fieldwork İn Geography Teaching: A Critical Review Of The Literature And Approaches, Journal Of Geography In Higher Education, 21(3), 313-332.

Koruklu, N., Feyzioğlu, B., Özenoğlu, K.H ve Aladağ, E. (2013). Öğretmenlerin İş Doyumu Düzeylerinin Bazı Değişkenlere Göre İncelenmesi, Mehmet Akif Ersoy Üniversitesi Eğitim Fakültesi Dergisi, 13(25), $119-137$. 
Köklü, M. (2012). Orta Öğretim Okulları Öğretmenlerinin Kararlara Katılma Durumları, Katılma İstekleri, İş Doyumları, Çatışmaları Yönetme Biçemleri. Eğitim ve Bilim, 37, 208-223.

Olorunsola, E.O. (2010). Job satisfaction and gender factor of administrativestaff in South west Nigeria Universities. EABREETLC Conference Proceeding, 91-95.

Özgen, N. (2011). Fiziki Coğrafya Dersi Öğretim Metoduna Farklı Bir Yaklaşım: Gezi- Gözlem Destekli Öğretim, Marmara Coğrafya Dergisi, 23, 373-388.

Öztürk, M. ve Eroğlu, E. (2013). Coğrafya Öğretmen Yeterlikleri ve Uygulamaların Değerlendirilmesi, Marmara Coğrafya Dergisi. 27, 630-659.

Sabuncuoğlu, Z ve Tüz, M. (2005) Örgütsel Psikoloji, Alfa Aktüel Basım Yayın. Bursa.

Sapancalı, F. (1993). Çalışanların Güdülenmesinde Kullanılan Özendirici Araçlar. Verimlilik Dergisi, Milli Prodüktivite Merkezi Yayınları. Ankara.

Shields, J. (2007). Social Servise Work And Job Satisfaction: Revisiting Herzberg, Mausr ESnyderman. Unpuhlished Master Thesis, B.S Southwest Missouri State University, USA.

Shraibman, F.K. (2008). An Examination Of The Job Satisfaction Of The Certified Public Accountants As It Relates To Their Area Of Practice And Their Locus Of Control. Unpublished Doctoral Thesis, New York University, USA.

Spector, P.E. (1997). Job Satisfaction: Application, Assessment, Cause, and Consequences. California: Sage.

Siripak, S. (2006). Job satisfaction of academic staff in Mahidol University. Unpublished master thesis. Mahidol University, Educational Faculty, Educational Management.

Şahin, H. ve Dursun, A. (2009). Okul Öncesi Öğretmenlerinin İş Doyumları: Burdur örneği. Mehmet Akif Ersoy Üniversitesi Ĕ̆itim Fakültesi Dergisi, 18, 160-174.

Taşdan, M. ve Tiryaki, E. (2008). Özel ve Devlet İlköğretim Okulu Öğretmenlerinin İş Doyumu Düzeylerinin Karşılaştırılması. Eğitim ve Bilim. 33, 54-70.

Türkçapar, Ü. (2012). Beden Eğitimi Öğretmenlerinin Farklı Değişkenler Açısından İş Doyumu Düzeylerinin İncelenmesi. GEFAD / GUJGEF 32 (2), 331-346.

Vural, B. (2004). Yetkin-İdeal-Vizyoner Ö̆gretmen. Hayat Yayınları. İstanbul.

Wagner, J.A. ve Hollenbeck, J.R. (2010). Organizational Behavior: Securing Competitive Advantage, Routledge. New York.

Weiss, D.J., Dawis, R.V., England, G.W. and Lofquist, L.H. (1967). Manual for the Minnesota Satisfaction Questionnaire. Vol. 22, Minnesota Studies in Vocational Rehabilitation, Minneapolis: University of Minnesota, Industrial Relations Center.

Zöğ, H. (2007). İstanbul İli Kâ̆ğthane İlçesinde Görev Yapan İlköğretim Okulu Öğretmenlerinin Örgütsel Adanmışlıkları ile İş Doyumları Arasındaki İlişki. Yıldız Teknik Üniversitesi Sosyal Bilimleri Enstitüsü Eğitim Bilimleri Ana Bilim Dalı Eğitim Yönetimi Ve Denetimi Yüksek Lisans Programı Yüksek Lisans Tezi, İstanbul. 


\section{Extended Summary}

\section{Purpose}

Job satisfaction refers to the personal satisfaction degree of the employees about their jobs. Teachers, who are dealing with one of the most self-sacrificing occupations, are the most strategic elements in fulfilling the objectives of education. Thereby, job satisfaction is much more important for the teachers. This study is carried out to analyze the job satisfaction levels of the geography teachers and to determine whether there is a meaningful difference between the job satisfaction levels in terms of different variables.

\section{Method}

Descriptive survey model was used in the study. The study was carried out with 324 geography teachers in total who are working in state and private schools in Turkey during the spring semester of 20142015 school year. The data was collected by using Personal Information Form and the Minnesota Job Satisfaction Questionnaire. Also, the statistical package of sciences, SPSS was used to analyze. Independent sample t-test, one-way analysis of variance (ANOVA), LSD and Scheffe test were used in the study.

\section{Findings}

According to the results of this study, it was determined that general job satisfaction levels of geography teachers were at the "medium" level. As a result of the findings, he job satisfaction ranking of the geography teachers in the study vary across the opportunities of the field exploration and excursion, the sufficiency of the equipments for the lecture and the variables of the institution and the school; yet, the ranking does not vary according to the teachers' gender, age and variables in the curriculum for geography.

\section{Conclusion and Recommendations}

The "medium-level satisfaction" finding in the research is not too bad for the name of teaching and geography; yet, it is not sufficient either. It shows us the necessity of doing prospective studies to increase the job satisfaction levels of the geography teachers.

According to the results of the study, the geography teachers have the same level of job satisfaction with respect to the age and gender variables. In this case, it can be said that the age and gender variables in the job satisfaction will be effective when integrated with other variables. In this study, it is concluded that the job satisfaction levels of geography teachers become much higher when they implement more field explorations and excursions, when they work in state schools or Anatolian high schools and when they have sufficient equipments for the lecture. It is highly important to determine the factors in which the teachers have job satisfaction or dissatisfaction; and thereby to take the necessary precautions. The weekly course hours of geography should be increased in the secondary schools. There must be geography laboratories in the schools, the smart boards must be used in the classrooms and also there should be much more frequent field excursions. 